\title{
THE CARRYING CAPACITY ON ECOSYSTEM SERVICES OF LAND USE CHANGE AT BORDER ENTIKONG
}

\author{
Robby Irsan ${ }^{*}$, Luthfi Muta'ali ${ }^{2}$, Sudrajat $^{3}$ \\ ${ }^{1}$ Doctoral Program of Environmental Science, Gadjah Mada University, Indonesia \\ ${ }^{2,3}$ Faculty of Geography, Gadjah Mada University, Indonesia \\ ${ }^{*}$ Corresponding Author (e-mail: beetreecyber110683@gmail.com)
}

Received: 29 June 2018/Revised: 17 July 2018/Accepted: 30 July 2018/Published online: 28 August 2018

\begin{abstract}
Entikong Region is located in Sanggau Regency, West Kalimantan Province, Indonesia, which is directly adjacent to Malaysia. Land use in the Border Area, which is massive and irregular, results in environmental degradation, deculturization, and lack of living standards of the community. High population growth in the border areas leads to excessive use of natural resources, and used land is not appropriately allocated. The land has limited function, and if the demand for the land is greater than the carrying capacity, there will be an imbalance that results in land degradation and its environment. The purpose of this study is to identify the type and extent of land function switch, analyze provider services as part of the Land Support Capacity Ecosystem services, and identify the Accuracy of Image Interpretation. The results showed that the increasing area of massive land use comes from a mixed plantation in 2017 increased by $60.6 \%$ of the total area of Entikong District. Degradation occurs in primary forest land use component which is only $18.6 \%$ of Entikong's total area in 2017. This indicates that the use of mixed plantation land acquires the protected forest, with many palm, rubber, and pepper. Similarly, the percentage of accuracy test from the interpretation result reaches $83.33 \%$ from 42 sample points in accordance with the real conditions. The Value of Clean Water Ecosystem Service Providers in 2011 was 0.36 and was 0.33 in 2017. Then within the period of almost 7 years, it is decreased by 0.03 . Thus, the Ecosystem Service Index of clean water providers has a value less than 1, it means the function of the area as a provider of clean water is very small. Similarly, the Provider Ecosystem Services Index for Foodstuffs, the Value of Food Ecosystem Services Index in 2011 was 0.32 and was 0.31 in 2017, then within the nearly 7-year period, it is decreased by 0.01 . The ecosystem services index as a food supply provider for the Entikong border area is very low (less than 1) which means the carrying capacity of the environment is not good enough for supplying food needs in Entikong. This indicates that there is a reduction in the availability of environmental services, and if it continues, then Environmental Assets declines sharply and services derived from nature will be lost or will be expensive in the near future. Thus, optimization and revitalization of land use are necessary by applying various policies related to development in the border area in Entikong District.
\end{abstract}

Keywords: Borders, Land Use, Ecosystem Provider Services.

\section{Introduction}

Entikong is located in Sanggau Regency, West Kalimantan Province, Indonesia, and directly adjacent to Malaysia (Sarawak) which has different characteristics (in the economic 
sector, institutional, zoning, and informal sector roles) both internally and externally. The lack of socialization about Land Use in the border area causes the degradation of natural resources and poor environmental quality, which is the cause of a low standard of living welfare. When the demand for resources goes beyond what nature can provide on an ongoing basis, it is called an ecological exploitation, and if carrying capacity declines, it is called overpopulation (Rustiadi and Saefulhakim, 2011).

One of the efforts taken to reduce the impact is by doing a fairly comprehensive evaluation of the effect of a land use activity on the quality and quantity of the existing environment. As a physical representation, improvement, and conversion of land that deviates from the designated land use. One of them is the use of plantation land (oil palm, rubber, and pepper) will have an impact on environmental degradation and declining availability of environmental services. If this continues, the Environmental Assets will decline sharply and the free environmental services will be lost or become expensive in the near future. Ecosystem services are categorized into four; provision services, arrangement, culture, and support (Riqqi, 2014).

Regional environmental services index value is a weighted index of each component of ecosystem services. Technically, the calculations are performed by several components in ecosystem services such as ecosystem services components that support clean water and food (Muta'ali, 2015). Based on the background that the researchers have conveyed the main purpose of this Research are: (1) Identify the extent and type of land use in Entikong. (2) Analyzing the level of accuracy of land use interpretation in Entikong. (3) Analyze the value of ecosystem services index from each variable of land use in Entikong.

\section{The Methods}

The research was conducted in West Kalimantan Province, at Entikong Border, Sanggau Regency, and directly adjacent to Malaysia (Sarawak). These data are grouped into primary and secondary data in 2011-2017. Primary data consists of Landsat Image in 2011 and 2017. Secondary data consists of maps of Entikong District Administration obtained from the Regional Development Planning Board in West Kalimantan Province, Sanggau Regency. The equipment used is Global Positioning System (GPS), a set of computers with ArcView GIS software, and Office 2007.

\subsection{Analysis of Land Use Map}

The source of land use maps is the result of digital interpretation of ETM Landsat Imagery in 2011 and Landsat 8 OLI in 2017. The process of digital interpretation is carried out 
with the help of the program ENVI 4.5. ETM Landsat Image 2011 and Landsat 8 OLI 2017 have low-resolution images with spatial resolution of 30 x $30 \mathrm{~m}$. This image is obtained from the USGS website. The image used has been undergone radiometric and geometry correction. The process of remote sensing data analysis starts from geometric correction of the image with topography map scale 1: 25.000 . Furthermore, the land use is described manually by visual interpretation techniques. The characteristic of the object used to recognize an object is called image interpretation (Saripin, 2003).The analysis of land use switch is carried out by comparing Land Use Map in 2011 with Land Use Map in 2017, in order to see the land use switch that happened from 2007 until 2017. The result of Landsat and Earth Map interpretation in 2007 and 2017 later are being overlayed to produce land use switch maps. The Land Use Map of Entikong in 2011 can be seen in Figure 1 and 2 below:

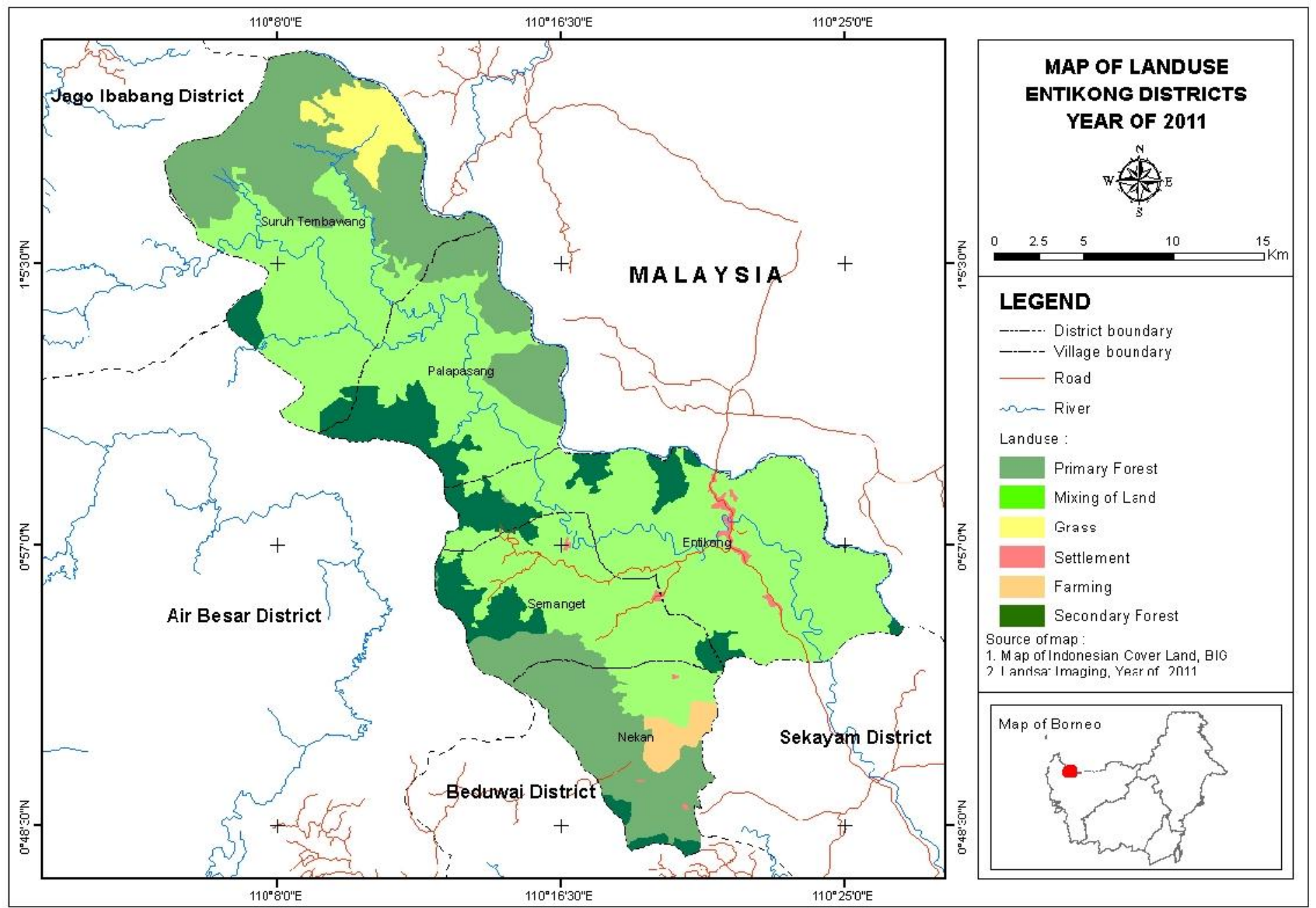

Figure 1.Land Use Map in 2011 (The result of ETM Landsat Imagery) 


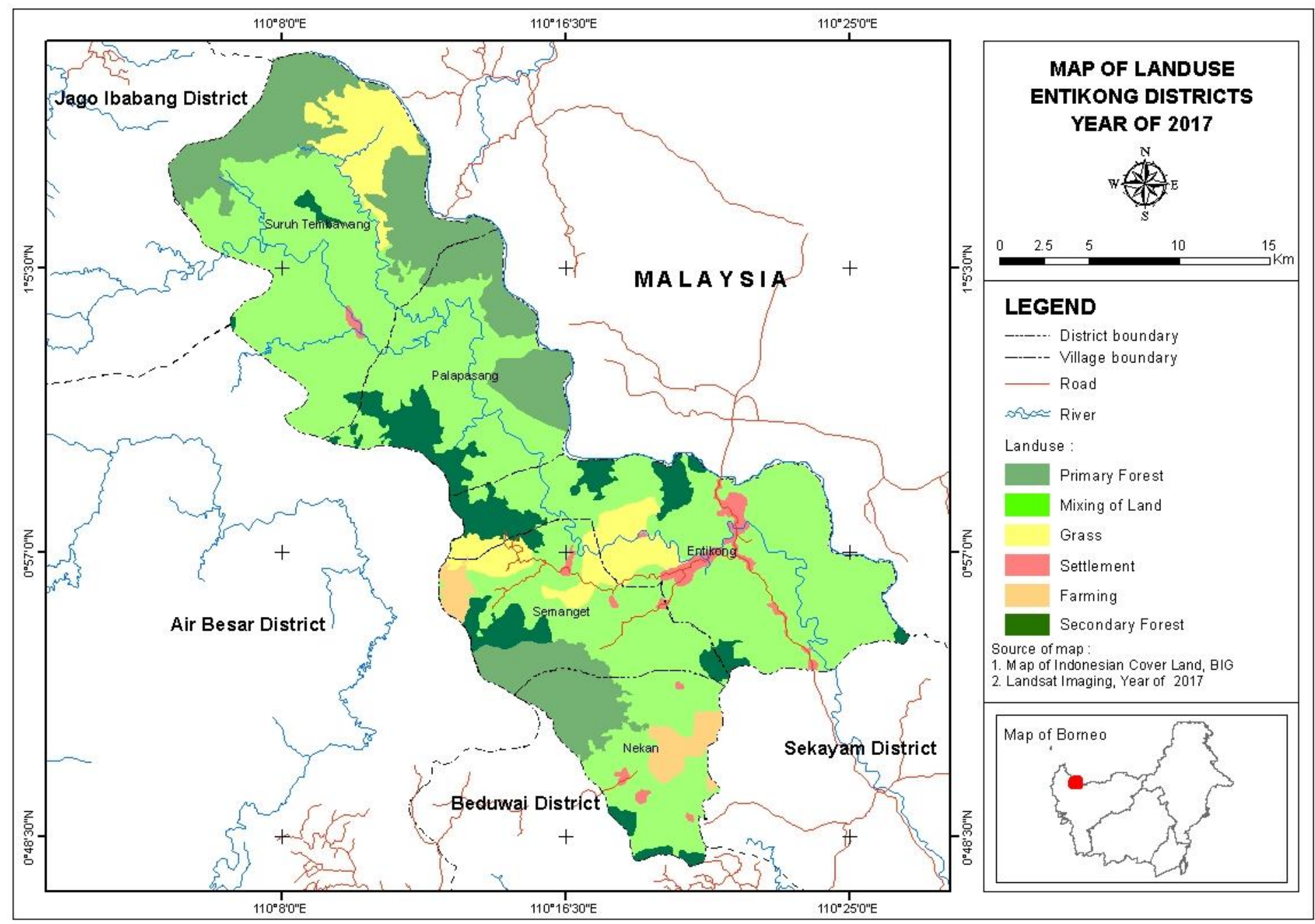

Figure 2. Land Use Map in 2017 (The result of ETM Landsat Imagery)

\subsection{Analysis of Land Use Switch}

Land use switch is presented in percentage with the following equation:

$\mathrm{V}=\mathrm{N} 2-\mathrm{N} 1 / \mathrm{N}$

Information:

$\mathrm{V}=$ rate of land use switch

$\mathrm{N} 2=$ area of land use in the second year

$\mathrm{N}=$ Total Area (Hamidy, 2003) 


\subsection{Accuracy Test of Image Interpretation}

The next step is determining the Land Use class used in the classification process. The land use class used in this study is based on land use classification by Sandy, 1977, which distinguishes between rural and urban land use. On a mapping scale of 1: 50,000 Land Use is divided into 10 classes with several subcategories (Purwadhi, 2008).

The interpretation results need to be checked using Field Survey method. The sampling method used is Purposive Sampling. The interpretation result is considered accurate if the percentage of conformity interpretation is more than $80 \%$ (Saripin, 2003). This method is used in the digital analysis of remote sensing data using a computer, but can also be used in the manual analysis or visual Remote Sensing data by converting pixels into square plots or widths for each class of interpretation results.

Table 1. Interpretation Accuracy Test

\begin{tabular}{|c|c|c|c|c|c|c|c|c|}
\hline $\begin{array}{c}\text { Interpretation } \\
\text { Data } \\
\end{array}$ & A & B & C & D & Amount & Omission & Comission & Mapping accuracy \\
\hline $\mathbf{A}$ & 25 & 5 & 10 & 3 & 43 & $\begin{array}{c}18 / 43= \\
42 \%\end{array}$ & $7 / 43=16 \%$ & $\begin{array}{c}25 /(25+18+7)= \\
50 \%\end{array}$ \\
\hline B & 2 & 50 & 6 & 5 & 63 & $\begin{array}{c}13 / 63= \\
42 \%\end{array}$ & $11 / 63=17 \%$ & $\begin{array}{c}50 /(50+13+11)= \\
68 \%\end{array}$ \\
\hline $\mathbf{C}$ & 3 & 4 & 60 & 5 & 72 & $\begin{array}{c}12 / 72= \\
42 \%\end{array}$ & $18 / 72=25 \%$ & $\begin{array}{c}60 /(60+12+18)= \\
67 \%\end{array}$ \\
\hline D & 2 & 2 & 2 & 100 & 106 & $\begin{array}{c}6 / 106= \\
42 \%\end{array}$ & $\begin{array}{c}13 / 106= \\
12 \%\end{array}$ & $\begin{array}{c}100 /(100+6+13)= \\
84 \%\end{array}$ \\
\hline Total & 36 & 61 & 78 & 113 & 284 & & & \\
\hline
\end{tabular}

Source: (Saripin, 2003)

Accuracy of all interpretation results $=\underline{25+50+60+100}$

\subsection{Analysis of Clean Water Supply Services}

Index of Clean Water Supply Service (JPL ab), has a range of values between 0 (minimum) to 1 (maximum). Therefore, if the value is closer to 1 , it means the function of the area as a provider of clean water is getting better.

The formula is:

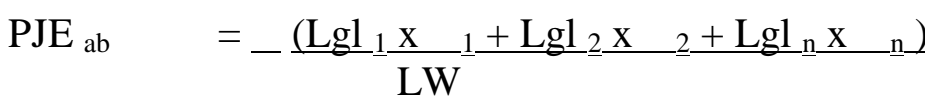

Information:

$\mathrm{PJE}_{\mathrm{ab}}=$ Clean Water Ecosystem Service Provider

$\mathrm{Lgl}_{1}=$ The Extent of Land Use Type 1 (ha)

LW = Total extent of the Area (ha)

$\alpha_{1}=$ Coefficient of water services for land use 1 ( Table 2 ) 
Here is The Coefficient Table of the Value of Water Supply Services :

Table 2. The Coefficient Table of the Value of Water Supply Services

\begin{tabular}{cccccccccc}
\hline & \multicolumn{10}{c}{ Land Use } \\
\cline { 2 - 11 } Ecosystem & Primary & Secondary & Mixed & Plantation & Settlement & Farm & Shrubs & $\begin{array}{c}\text { Body of } \\
\text { water }\end{array}$ & Field \\
$\begin{array}{c}\text { Services } \\
\text { Clean Water }\end{array}$ & Forest & Forest & Garden & Field & & 0,172 & 0,559 & 0,237 \\
Supply Service & 0,516 & 0,516 & 0,280 & 0,237 & 0,129 & 0,215 & 0,172 & \\
\hline
\end{tabular}

Source: Ecosystem Services Index Value (Riqqi, 2014)

\subsection{Analysis of Food Supply Service}

The Food Service Provider Index (JPL bp), has a value range between 0 (minimum) to 1 (maximum). Therefore, if the value is closer to 1 , it means the better the function of the area as a food provider is getting better.

The Formula is:

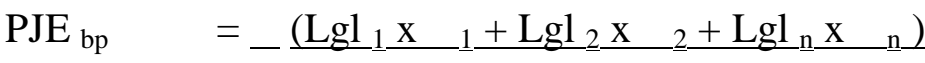

$$
\begin{aligned}
& \text { LW }
\end{aligned}
$$

Information:

$\mathrm{PJE}_{\mathrm{bp}}=$ Ecosystem Service Provider for Food Supply

$\mathrm{Lgl}_{1}=$ The Extent of Land Use Type 1 (ha)

$\mathrm{LW} \quad=$ Total extent of the Area (ha)

$\underline{\beta}_{1}=$ Coefficient of food ecosystem services for land use 1 (Table 3)

Here is The Coefficient Table of the Value of Food Supplier Services :

Table 3. The Coefficient Table of the Value of Food Supplier Services

\begin{tabular}{|c|c|c|c|c|c|c|c|c|c|}
\hline \multirow[b]{2}{*}{$\begin{array}{c}\text { Ecosystem } \\
\text { Services }\end{array}$} & \multicolumn{9}{|c|}{ Land Use } \\
\hline & Primary Forest & $\begin{array}{l}\text { Secondary } \\
\text { Forest }\end{array}$ & $\begin{array}{c}\text { Mix } \\
\text { Garden }\end{array}$ & Plantation & Settlement & $\begin{array}{l}\text { Farm } \\
\text { Field }\end{array}$ & Shrubs & $\begin{array}{c}\text { Body } \\
\text { of } \\
\text { water }\end{array}$ & Field \\
\hline $\begin{array}{c}\text { Food Supplier } \\
\text { Services }\end{array}$ & 0,289 & 0,289 & 0,357 & 0,391 & 0,034 & 0,476 & 0,102 & 0,238 & 0,357 \\
\hline
\end{tabular}

Source: Ecosystem Services Index Value (Riqqi, 2014)

\subsection{Research Variable}

The classification system used is based on the SNI cover classification and land use in 2010 from Badan Standarisasi Nasional (BSN)

Here is the table: 
Table 4. Land use classification

\begin{tabular}{|c|c|c|}
\hline No & Classification & Information \\
\hline 1 & Primary Forest & $\begin{array}{l}\text { The forests that have a dense structure of plants that make the sunlight cannot touch } \\
\text { the ground. }\end{array}$ \\
\hline 2 & Secondary Forest & Forests that have experienced a succession \\
\hline 3 & Plantation & Land used for agriculture with harvest time of approximately two years \\
\hline 4 & Mixed Garden & $\begin{array}{l}\text { The types of garden that have high levels of density, overgrown by various types of } \\
\text { forest plants and agricultural crops. }\end{array}$ \\
\hline 5 & Settlement & Land used as a residence \\
\hline 6 & Shrubs & $\begin{array}{l}\text { Dryland which is overgrown with heterogeneous natural vegetation, dominated by } \\
\text { bushes and grasses whose existence is not managed by humans. }\end{array}$ \\
\hline
\end{tabular}

Source:(National Standardization Department, 2010)

\section{Results and Discussion}

\subsection{Land Use Switch/Change in 2011 and 2017}

Table 5. Changes in Land Use of Each Village in 2011 - 2017

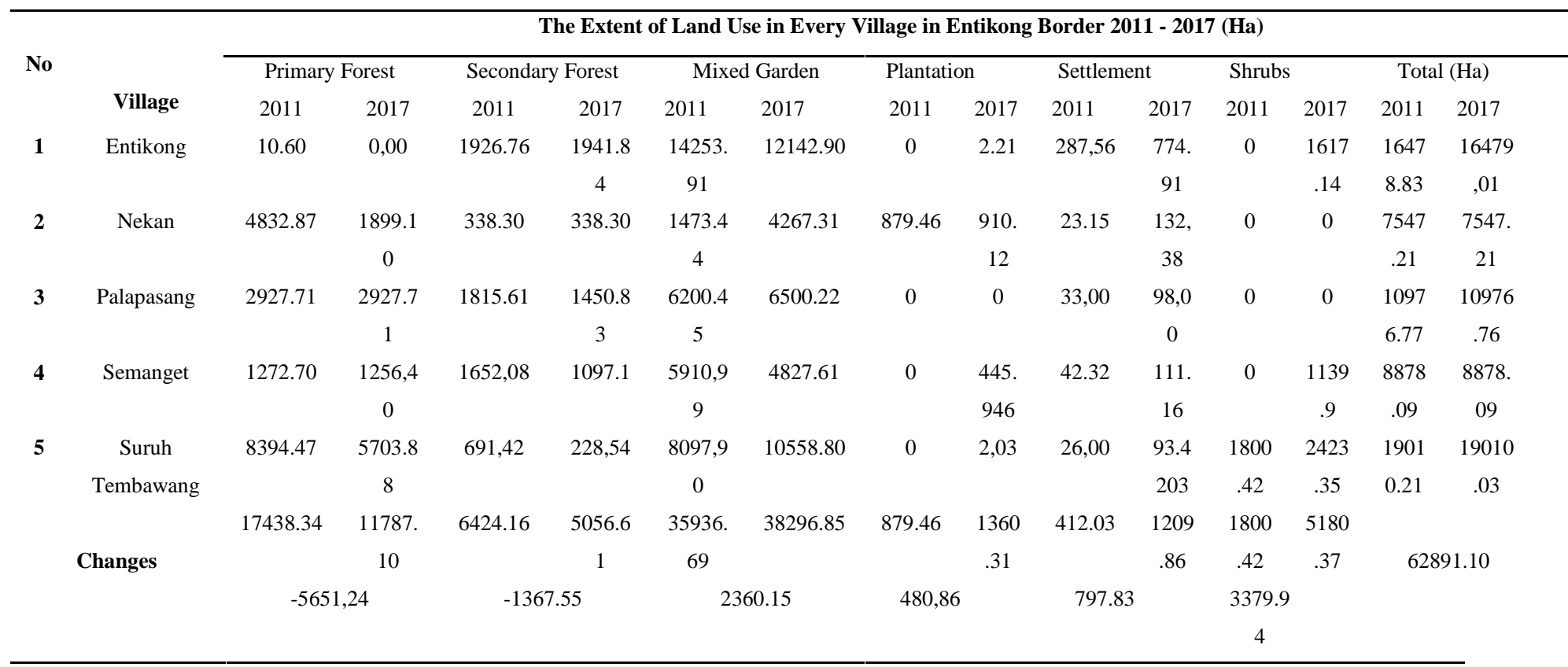

Source: Land Use Analysis Results 2011 -2017

There are 6 types of land use in Entikong sub-district in 2011; Primary Forest, Secondary Forest, Mixed Garden, Plantation, Settlements, and Shrubs. The extent or width of each type of land use is: Primary forest 174,38 km2 (27,72\%), Secondary Forest 64,24 km2 (10,25\%), Mixed Garden 359,56 km2 (57,17\%), Plantation 8.79 km2 (1.40\%), Settlement 4.12 $\mathrm{km} 2(0.56 \%)$, and Shrubs $18 \mathrm{~km} 2(2.90 \%)$. 
From the table above, it can be observed that the most dominant land use in Entikong sub-district in 2011 is mixed garden which covers $57.17 \%$ of all parts of the area and is distributed almost evenly in Entikong District, while the smallest type of land use is Settlements covering 0.56\%, or less than $1 \%$ spread in every village in Entikong District with an area of $3.53 \mathrm{~km} 2$ from all parts of Sanggau, West Kalimantan Province.

There are 6 types of land use in Entikong sub-district in 2017: Primary Forest, Secondary Forest, Mixed Garden, Plantation, Settlements, and Shrubs. The extent or width of each type of land use is: Primary forest $117.87 \mathrm{~km} 2$ (18.74\%), Secondary Forest $50.56 \mathrm{~km} 2$ (8.05\%), Mixed Garden $382.96 \mathrm{~km} 2$ (61.05\%), The plantation $13.6 \mathrm{~km} 2$ (2.16\%), the settlement $12.09 \mathrm{~km} 2(1.77 \%)$, and Shrubs of $51.8 \mathrm{~km} 2(8.23 \%)$.

\subsection{Land Use Changes in 2011 and 2017}

The results of the interpretation conducted on Landsat Image in 2017 is the classification of Land Use in Entikong Sub-district into 6 types; primary forest, secondary forest, mixed plantation, plantation, settlement, and shrub. The percentage has shown an increase and decrease in the extent and type of land use. Massive land conversion occurs in plantation areas where forest land is used by communities for oil palm, rubber and pepper plantations.

Here are the charts showing the land use switch:

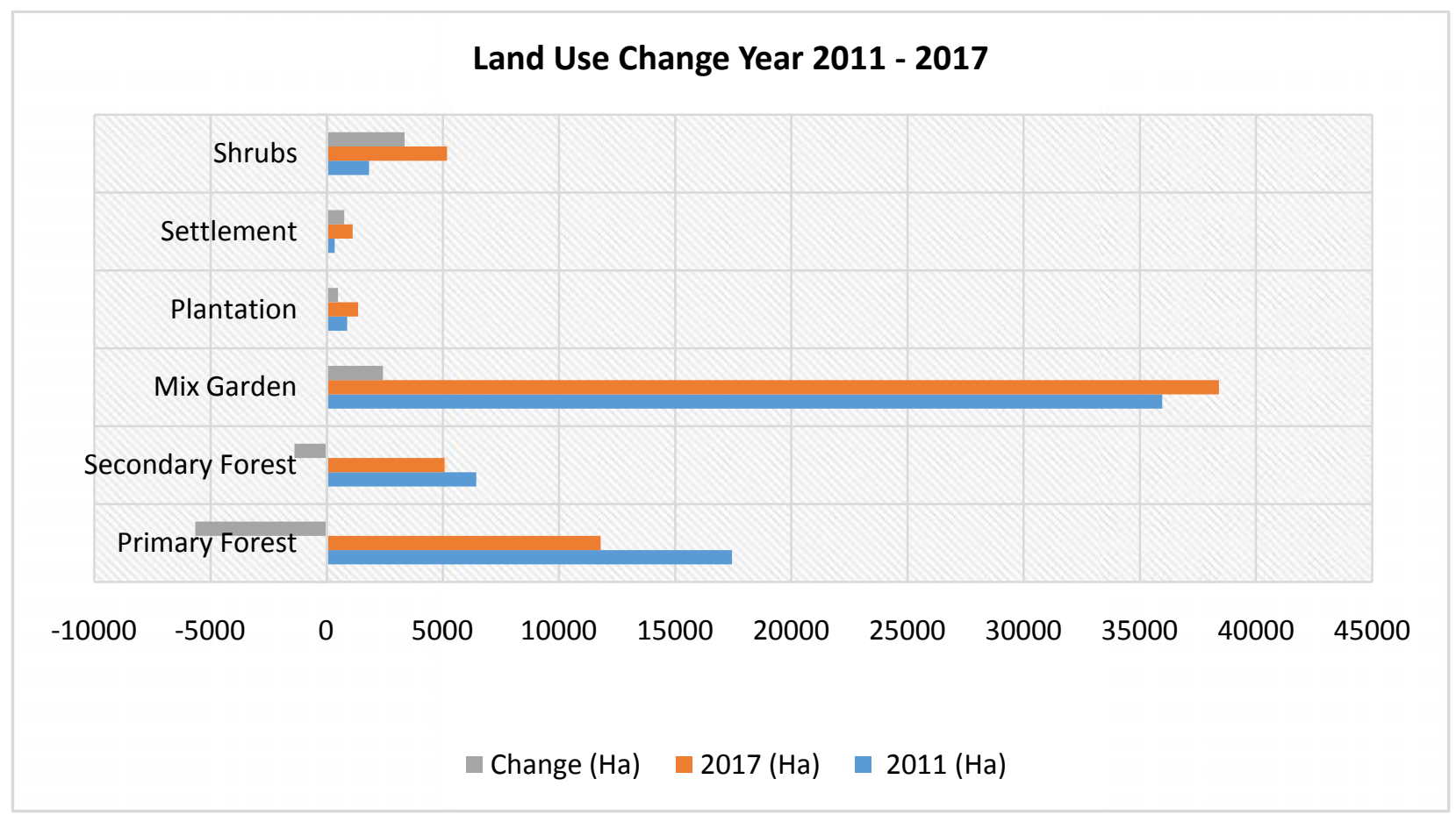

Figure3. The Analysis of Land Use Switch Result 


\subsection{The accuracy of Interpretation Test Results}

To know the accuracy and appropriateness of the result, remote sensing image interpretation is also done. The level of interpretation accuracy is reliable or interpretation of results is necessary or not for further analysis. Here is the Image of Test of Land Use Accuracy:

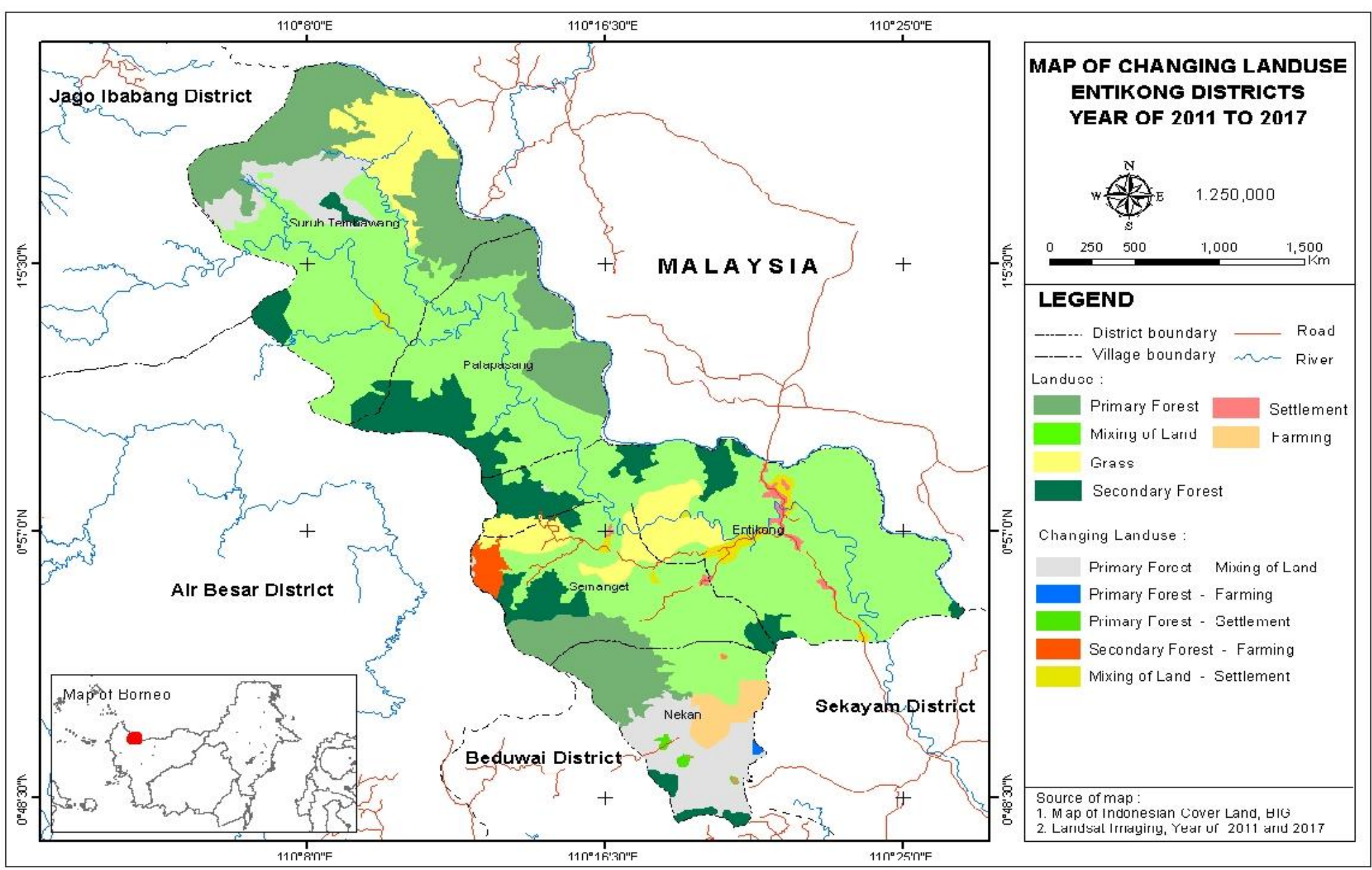

Figure 4. Sample Maps of Test Point for Land Use Accuracy (by Landsat Image ETM)

Land Use Map is the result of digital interpretation of Landsat Image ETM conducted in 2011 and Landsat 8 OLI in 2017. The process of digital interpretation is done using the ENVI 4.5 program. image Landsat ETM 2011 and Landsat 8 OLI 2017 are low-resolution images with spatial resolution of $30 \times 30 \mathrm{~m}$. This image is obtained from the USGS website. The image used has been corrected by radiometric correction and geometry correction. The image is then classified using the maximum likelihood method. The result of visual interpretation of land use validation test with field data is 42 points. The result of calculation of accuracy test using 
configs matrix, the result of digital land cover interpretation is validation test with field data that is 42 points. Here are the results of the calculation of accuracy test using the confius matrix:

Table 6: The Result of Land Covering Test

\begin{tabular}{|c|c|c|c|c|c|c|c|c|c|}
\hline \multirow{8}{*}{$\begin{array}{c}\text { Data } \\
\text { Interpretation }\end{array}$} & \multicolumn{9}{|c|}{ Field Data } \\
\hline & $\begin{array}{c}\text { Land } \\
\text { Covering }\end{array}$ & $\overline{\mathbf{A}}$ & B & $\mathrm{C}$ & D & $\mathbf{E}$ & $\mathbf{F}$ & Total Sample & Appropriate \\
\hline & A & 7 & & & & & & 7 & 7 \\
\hline & B & & 4 & 1 & 2 & & & 7 & 4 \\
\hline & C & & & 6 & 1 & & & 7 & 6 \\
\hline & D & & 1 & & 6 & & & 7 & 6 \\
\hline & $\mathbf{E}$ & & & & & 7 & & 7 & 7 \\
\hline & $\mathbf{F}$ & & & & 2 & & 5 & 7 & 5 \\
\hline Sample Amount & & 7 & 5 & 7 & 11 & 7 & 5 & 42 & 35 \\
\hline
\end{tabular}

(Source: The Result of data processing and field inspection, 2017)

Information:

$\mathrm{A}=$ Primary Forest

$\mathrm{B}=$ Mixed Garden

$\mathrm{C}=$ Shrubs

$\mathrm{D}=$ Secondary Forest

$\mathrm{E}=$ Settlement

$\mathrm{F}=$ Plantation

Accuracy percentage $=$ The appropriate number of samples $\times 100$

$$
\begin{aligned}
& =35 / 42 \times 100 \\
& =83,33 \%
\end{aligned}
$$

\subsection{Analysis of Foodstuff Supply Ecosystem Services in Entikong District in 2011 and 2017}

Regional environmental services index value is a weighted index of each component of ecosystem services. The following is the calculation of food ecosystem services provider in 2011 and 2017. Based on the value of Food Supplier Ecosystem Services Index in 2011 in the amount of 0.32 and in the year 2017 in the amount of 0.31 , then in the period of almost 7 years, it is decreased by 0,01 . Obviously, this is not good because the ecosystem service index as a food supply provider for the Entikong border area is very low, it has a value of less than 1 . The lower (near 0) means the environmental carrying capacity is not too good to supply Entikong border food needs. Here are the Analysis Results of Coefficient Results of Food Supply Ecosystem Service Providers: 


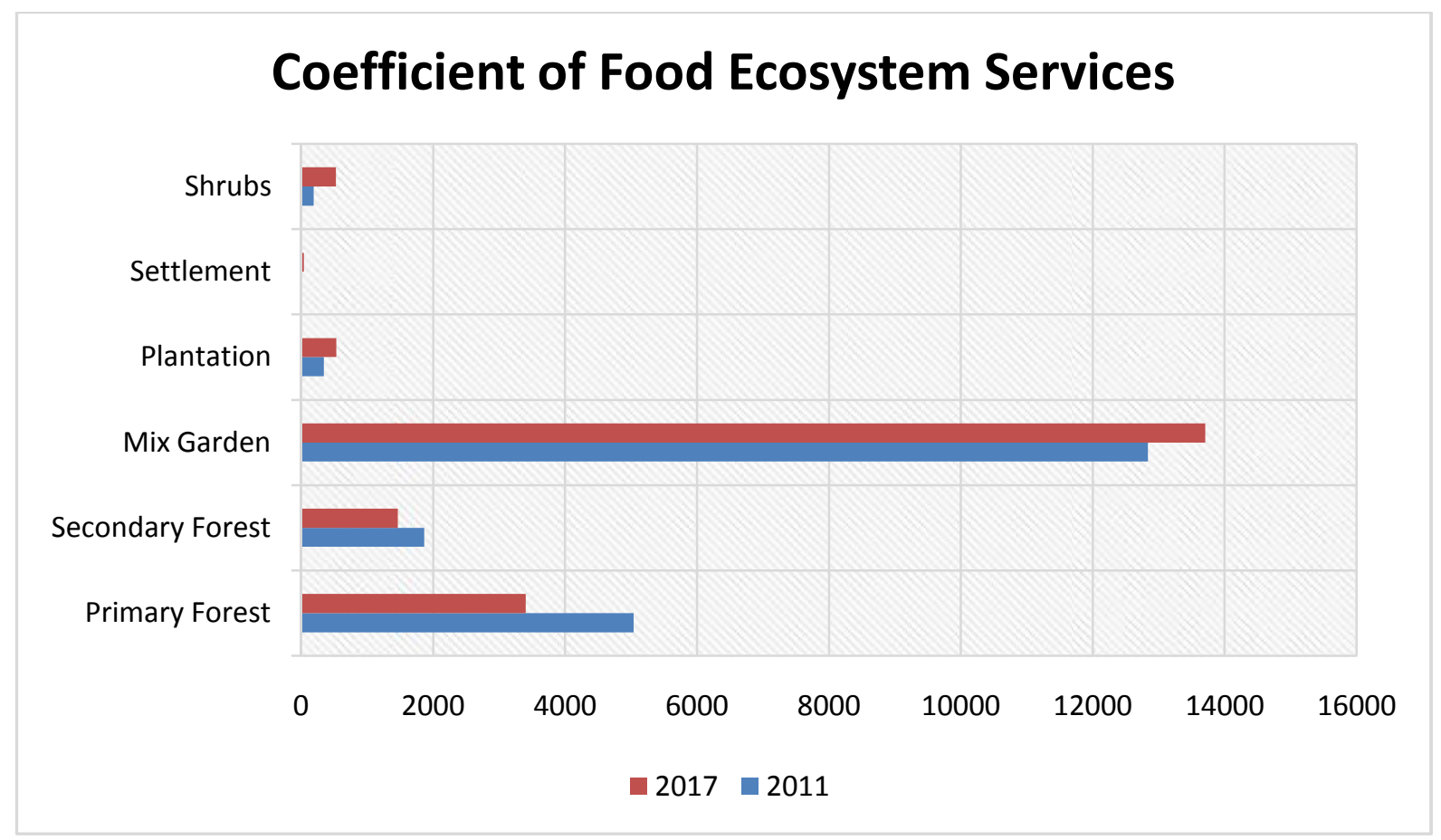

Figure 5: Analysis Results of Coefficient Results of Food Supply Ecosystem Service Providers

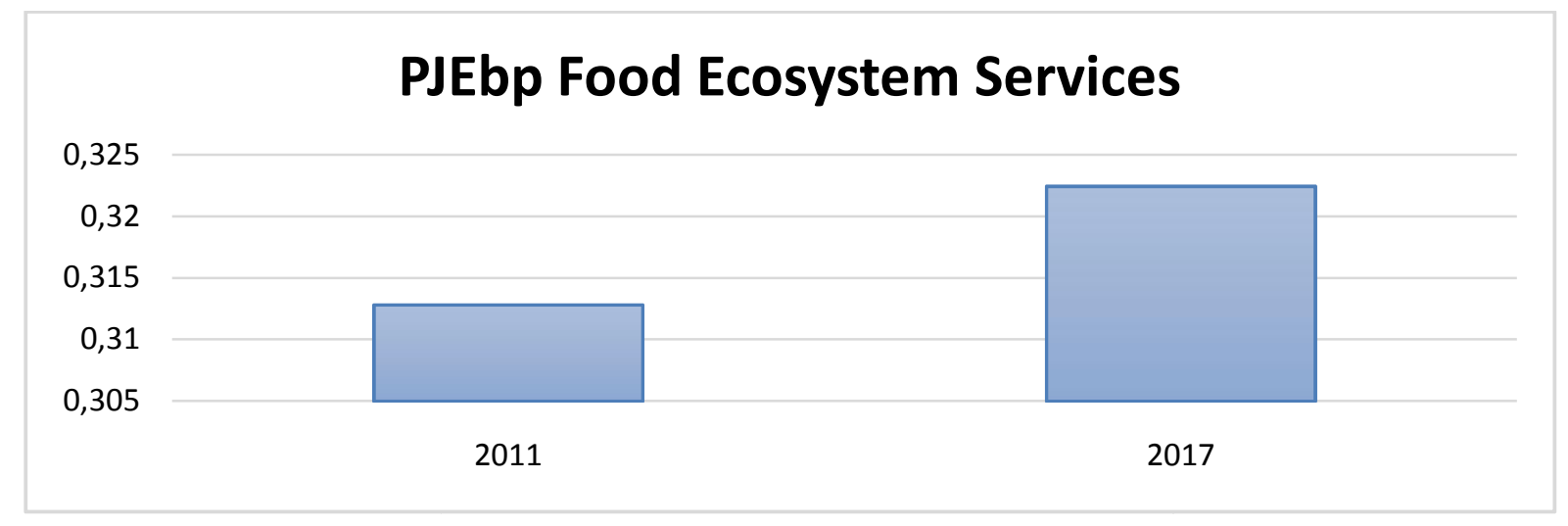

Figure 6: Analysis Results of Foodstuff Supply Ecosystem Services

\subsection{Analysis of Clean Water Ecosystem Services in Entikong Sub District Year 2011 and 2017}

The value of the regional service environment index is the value of the area index of each component of the ecosystem services. With the value of clean water ecosystem services index in 2011 in the amount of 0.36 and in the year 2017 in the amount of 0.33 , then in the period of almost 7 years, it is decreased by 0.03 . This is not good for the environment because the ecosystem service index as a provider of clean water for Entikong border area is very low because it has a value less than 1 . The lower (near 0 ) then the environmental carrying capacity 
is not very good, means the function of the area in water supply services is bad. The following is the calculation of water supply ecosystem services in 2011 and 2017:

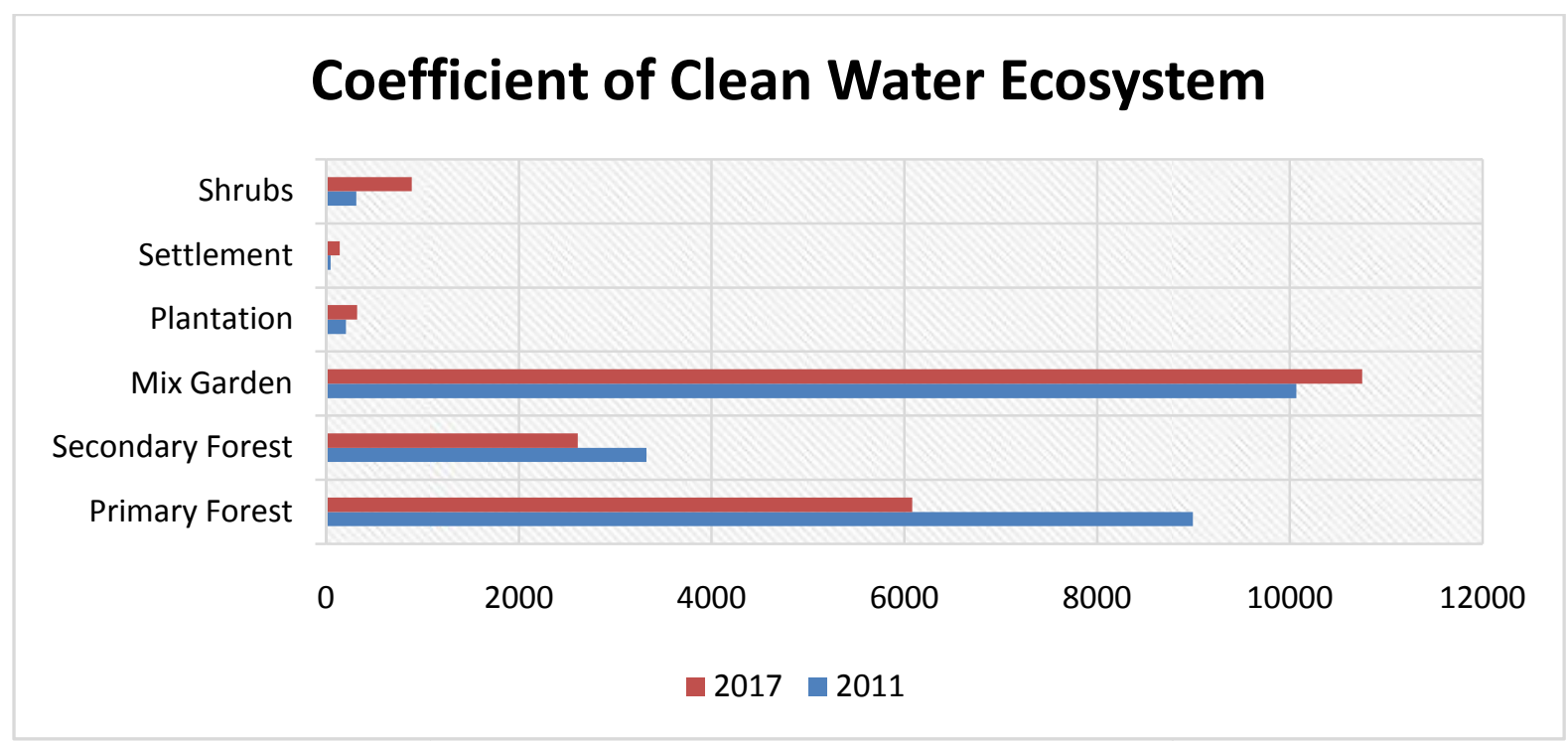

Figure 7: The result of Clean Water Ecosystem Services Coefficient Analysis

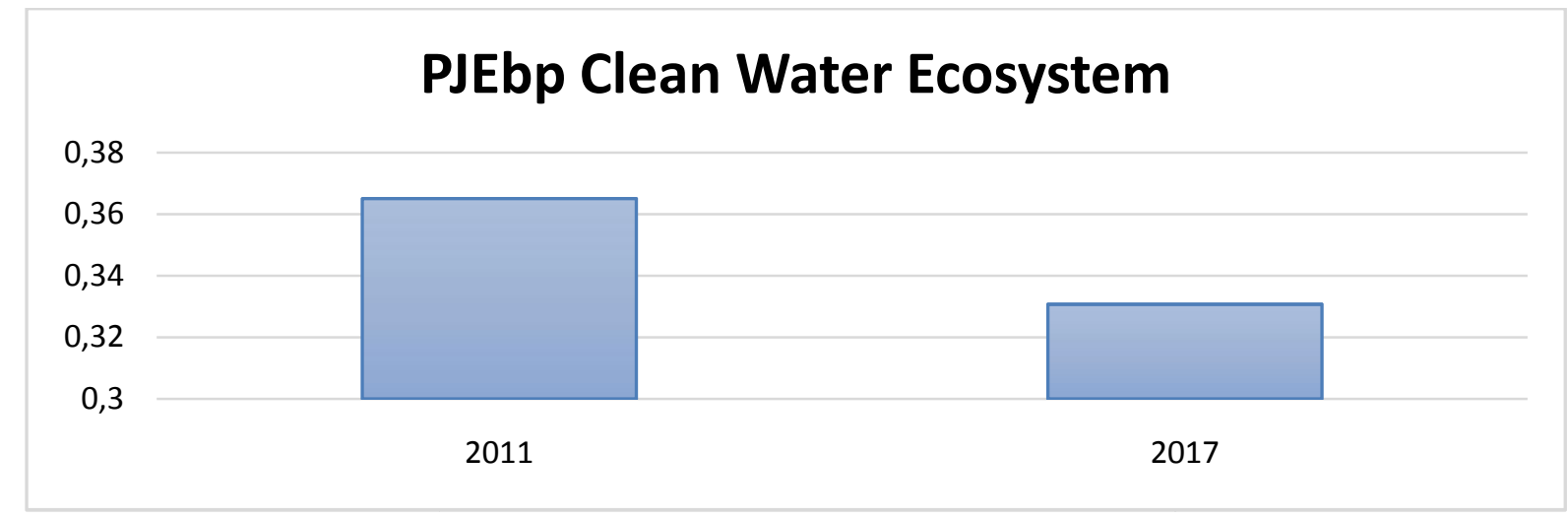

Figure 8: The result of clean water ecosystem services analysis

Research information on land carrying capacity and land use switch have been widely practiced. examines spatial planning derived from the support based on water resource capacity (Asdak \& Salim, 2006). This research is descriptive and does not discuss thoroughly and in detail about water resources management. The results of this study are ecosystem approaches that place production sub-subsystems, consumption sub-systems, and distribution sub-systems in the context of interconnection among components in the overall water resource management system.

Subsequent research, (Viska, 2012) assessed the carrying capacity through an ecological footprint approach which is a study of the carrying capacity to assess the 
environmental carrying capacity of an area toward its natural resource consumption level. The results of this study found the carrying capacity of each type of ecological land use in Batu City Malang where the agricultural land surplus demand of 827.54 gha and supply of 3,458.4 gha, forest land has a demand deficit of 49,081 gha and supply of 3,271 gha. In addition, carbon sinks have a demand of 212,648 gha with biocapacity land assumed by forest land. The objective of the analysis is that forest land can be developed and maintained as a consequence of the deficit condition experienced by each component. Further Research (Ghozali, 2013), examines the supporting components of land use optimization in Gresik Regency. The method used is through an ecological footprint approach where it can measure the level of natural resource consumption and the ability of the land to provide for consumption needs.

The results showed that the highest percentage of biocapacity in agricultural land was $53.92 \%$. However, the biocapacity is not proportional to ecological footprint consumption of 1.63 million gha due to high population and activity. This reinforces the unbalance condition of environmental carrying capacity in Gresik Regency with the ecological deficit. Research results of Varika (2015) states the environmental carrying capacity of the recreational ecosystem and ecotourism services based on land use and landscape aspects using remote sensing i.e. Landsat 7 Image ETM + and 8 OLI. The results showed that the distribution of the most dominant provision of Ecotourism Service Index lies in the use of building land. Further Research Admadhani, Hajil, \& Susanawati (2013) examines the status of environmental carrying capacity based on monthly water availability and water demand in Bojonegoro regency. The method used is quantitative analysis through comparison between the calculation of water availability and demand. The calculation result of the environmental carrying capacity status is in the exceeded category (overshoot).

My research studies are related to the carrying capacity of service providers, especially in ecosystems. The research related to water and land ecosystem services has never been done, although the research is still within the scope of carrying capacity, the approach used is different from previous research. What makes this research distinguishes from previous research is that this research is tested with the accuracy of interpretation, and approach used is the approach of ecosystem services for food providers and water supply. In addition, the location of research is located on the border of Indonesia-Malaysia, especially Entikong makes it different from previous research.

From Table 5 above, it can be observed that the most dominant land use in Entikong District in 2017 is mixed Garden type, covering 61.05\% of all areas and distributed almost evenly in Entikong District, while the smallest type of land use is settlement, which covers 
$1.77 \%$, spreading in every village in Entikong District with an area of $11.11 \mathrm{~km} 2$ from all parts of the district. Another case with Primary Forest depreciates by 5,651.24 Ha within 6 years, i.e. from 2011 to 2017. This indicates that there is overlapping of inappropriate and unbalanced land use. Furthermore, in the table, the interpretation test results of $83.33 \%$ of the 42 samples from the point taken indicates the suitability between the sample Map within the field.

In Figure 6, the value of Food Supply Ecosystem Services Index in 2011 is in the amount of 0.32 and in 2017 is in the amount of 0.31 , then in almost 7 years period, it is decreased by 0.01 . This is not good because the ecosystem service index as a food supply provider for the border area in Entikong sub-district is very low and has a value of less than 1. Similarly, the value of Clean Water Ecosystem Services Index in 2011 is 0.36 and in 2017 is 0.33 , then in the nearly 7-year period, it is decreased by 0.03 (see Figure 8 ). This is not good because the ecosystem service index as a clean water provider for the Entikong District border area is very low because it has a value of less than 1 and indicates that the relationship between the availability of ecosystem services and the environmental capacity is exceeded (overshoot), the value of ecosystem services clean water provider index is a resource management tool that can measure how much human resources the population needs, to produce the resources consumed. Rustiadi and Saefulhakim (2011) says that if the demand for availability exceeds and nature cannot provide a continuous need is called an ecological Overshoot.

\section{Cloncusion}

Research study on overlay method, interpretation test, and method of carrying capacity of ecosystem services of water supply providers and foodstuffs used serves to see how far the availability and carrying capacity. Natural and environmental resources produce two products in the form of goods and services. Services products are also called environmental services, i.e. benefits derived from non-natural goods but environmental functions such as water systems, climate, clean water, biodiversity, beauty, coolness and so on (Muta'ali, 2015). The findings in this study are related to land use change with the availability of ecosystem services, especially in border areas that have high population levels. The value of environmental balance between availability and demand must be observed because of the very limited carrying capacity of the environment in the next few years. The relationship between land use switch analysis over a 2 year period was obtained from Landsat ETM Image overlay in 2011 and Landsat 8 OLI in 2017. The digital interpretation process was conducted with the help of the ENVI 4.5 program. Landsat ETM Image 2011 and Landsat 8 OLI 2017 are low-resolution images with spatial resolution of $30 \times 30 \mathrm{~m}$. This image is obtained from the USGS website. The image used has 
been done radiometric correction and geometry correction. The image is then classified using the maximum likelihood method. The result of visual interpretation of land use validation test with field data that is as much as 42 point. The result of calculation of accuracy test using confius matrix. The result of digital land cover interpretation is validation test with field data that is as much as 42 point. The image used has been corrected by radiometric correction and geometry correction. The image is then classified using the maximum likelihood method. The result of visual interpretation of land use validation test with field data is 42 points. The result of calculation of accuracy test using confius matrix, the result of digital land cover interpretation is validation test with field data that is 42 points. Here are the results of the calculation of accuracy test using confius matrix. The value of environmental balance between availability and demand must be observed because of the very limited carrying capacity of the environment in the next few years. The relationship between land use switch analysis over a 2 year period was obtained from Landsat ETM Image overlay in 2011 and Landsat 8 OLI in 2017. The digital interpretation process was conducted with the help of the ENVI 4.5 program. Landsat ETM Image 2011 and Landsat 8 OLI 2017 are low-resolution images with spatial resolution of $30 \times 30 \mathrm{~m}$. This image is obtained from the USGS website. The image used has been done radiometric correction and geometry correction. The image is then classified using the maximum likelihood method. The result of visual interpretation of land use validation test with field data that is as much as 42 point. The result of calculation of accuracy test using confius matrix. The result of digital land cover interpretation is validation test with field data in the amount of 42 points. Furthermore, referring to the coefficient of clean water service providers and providers of foodstuffs, ecosystem services assessment index is done. If the index value is closer to 1 , it means the better the region functions in providing the environment sercive. On the other hand, if the index value is below 1 , it means that the area function to support the needs of human populations will be reduced or not good for environmental functions. This is the particular thing differentiates this study and the previous studies, where prior research has emphasized more on ecosystems. The research location is in the border area of the Republic of Indonesia and Malaysia, makes this Research is highly recommended for the stakeholders to produce policies related to border areas, especially in the field of Environmental Science, and improve alternative land use in accordance with its allocation in aligning and balance out the availability of resources and the environment. 


\section{Acknowledgments}

I am thanking Mr. Luthfi Muta'ali, and Dr. Sudrajat for providing willingness and time in research consultation, as well as prayer and support from his beloved wife Yulfitri and beloved son Ahsin Rifa in completing this research.

\section{References}

Admadhani, D. N., Hajil, A. H. S., \& Susanawati, L. D. (2013). Analysis of Water Supply and Water Demand for Carrying Capacity Assessment ( Case Study of Malang ). Journal of Natural Resources and Environment.

Asdak, C., \& Salim, H. (2006). Water Resource Capacity As a Spatial Planning Consideration. Journal of Environmental Engineering P3TL-BPPT.

Ernan Rustiadi, Sunsus Saefulhakim, D. R. P. (2011). Planning and Regional Development. Restpent Press.

Ghozali. (2013). Referral of Land Use Utilization Through Ecological Footprint in Gresik Regency. Territory and Environment, 1 No.1, 67-78.

Hamidy, Z. (2003). Land Cover Change, Composition, and Life Type in Suakaidupan Cikepuh. Faculty of Forestry, IPB.

Muta'ali, L. (2015). Regional Analysis Techniques For Regional Planning, Spatial Planning, and Environment (Februari). Yogyakarta: Faculty of Geography UGM.

National Standardization Department. (2010). Classification of Land Cover.

Purwadhi. (2008). Introduction Remote Sensing Imagery Interpretation. Semarang: LAPAN.

Riqqi, A. (2014). Design Concept Techniques Determination of Supporting Capacity and Capacity of the National Environment and Islands / Islands And Provinces. Bali: KLH.

Saripin, I. (2003). Identify Land Use Using Landsat TM Imagery. Agricultural Engineering Bulletin.

Varika. (2015). Monitoring of Ecosystem Service-Based Ecotourism (Recreation and Ecotourism) Capacity in 2000 and 2015 Using Landsat Image in Badung Regency, Bali.

Viska. (2012). Land Use Direction in Batu City Based on Ecological Ecosystem Approach. Pomits Technique, 1 No.1, 1-6. 